URL: www.cdetu.edu.np

Original Research Article

\title{
Teaching History of Bravery and the Politics of Textbooks in Nepal: A Critical Discourse Analysis
}

\author{
Saroj G.C. \\ Department of English, Nepal Commerce Campus, Kathmandu, Nepal
}

Article History: Submitted 10 June 2021; Revised 6 July 2021; Accepted 5 August 2021

Corresponding Author: Saroj G.C., Email: sarojgc1@gmail.com

DOI: https://doi.org/10.3126/sjah.v3i2.39417

Copyright 2021 () The Author(s). The work is licensed under a Creative Commons Attribution 4.0 International License (CC BY 4.0).

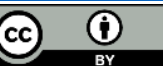

\begin{abstract}
This paper examines a saga of the brave history of Nepal which has often been part and parcel of school education in Nepal. The brave history in the textbooks has been treated as a means of enlightenment and a catalyst to cultivate national character. On close inspection, however, teaching history embarks a political enterprise - an articulation of interest to shape the idea of the citizenry. Using the method of critical discourse analysis and post-historicist ideas, this paper takes historical accounts attributed to three pillars of the national narrative of brave history - Bhimsen Thapa, Balbhadra Kunwar, and Prithvi Narayan Shah, as depicted in the government school textbooks for analysis. The paper examines how the history of bravery has been negotiated and maintained as a comfortable and simplistic narrative at the cost of teaching history more critically in order to inform students and examine emerging questions about the national heroes by excluding the other side of historical narratives. Finally, this paper proposes education at any level cannot be taken as value-neutral, and history should be studied historically.
\end{abstract}

Keywords: Education, history, nation, politics of textbooks, ideology

\section{Introduction}

History, as a dominant mode of knowledge-making, has been considered as having practical pedagogical functions: providing the sense of where we came from the definition of "who we are," empowering the learners with the skills analyzing, evaluating and interpreting, and imparting objective knowledge to understand other resources of knowledge (Smith 22; Tosh 29; Issitt 689). Aligning with the same functions, the Nepal's history of bravery that emerged after the unification/ expansion ${ }^{1}$ process of Prithvi Narayan Shah has ever been the content of learning in school textbooks. The history in school textbooks makes inroads not only to history lessons but also to the lessons of language and civic learning in diverse forms such as individual biographies, letters, short plays, poems, and so on. Much of the content concentrates more on constructing bira itihāsa as a shared national narrative to be passed on. In this sense, the dissemination of the history of bravery through government-sponsored schools takes the route of 
preserving and communicating "cultural truths intergenerationally" (Porat 51). The content attempts to form collective identities based on the power of the (common) past. History teaching thus the construction of national narrative is requisite for what Grever and Vlies call "the formation of a cohesive national identity" (287). In other words, few figures like Prithvi Narayan Shah, Balbhadra Kunwar, Bhimsen Thapa are always present in the textual memory of school textbooks.

However, the representation of history cannot be taken for granted since the authors or curriculum can "mix the certainty and illusion" in the textbooks and can change the "status" of history if not the historical content (Ferro 237). If the status of history is changed, teaching history can "never can be neutral or indifferent in regard to the reproduction of the dominant ideology or the interrogation of it" (Freire 91). More importantly, nationalized history education can be used to promote national ethos and feelings because it provides a shared national narrative (Bermudez 217-218; Carretero and et al. 3-4). Among other school subjects, history may be the most politically sensitive, and the one which most reflects the culture and politics of society; it is a legitimating phenomenon serving to define national identity and ideology. Therefore, it is equally crucial to acknowledge that secondary or primary sources of history must be approached with skepticism and caution since historians are inevitably "subjective" (Foucault 79-86; Carr 134). If the "status" of history is vulnerable, history as represented in the school textbooks should be a subject of scrutiny. In this light, the paper contends that the evocation of brave history has been one of the major means of textualization of national history in school education. Through the evocation of birra itihāsa ('brave history'), strategic deployment of the common past, the government-sponsored school textbooks try to form a homogenized collective identity as a requisite for the formation of a cohesive national identity.

\section{Review of Literature}

While representing historical facts, any curriculum or textbook can deploy either of two tendencies: witting the testimony and unwitting the testimony. "Witting testimony" is the deliberate or intentional message of a historical document or other sources; the "unwitting testimony" is the unintentional evidence tainted, for example, by the attitudes and values of the author, or the "culture" to which he/she belongs (Marwick 216-218). Actually, it is the creators as the source of documents who are "intentional" or "unintentional", not the testimony itself. In this sense, the "status" of history is vulnerable enough for giving away for subjective manipulation. In addition, the modern historicist thinkers believe that many who call themselves "historians" do, indeed, use "history" as a vehicle for expressing their own political commitment and agenda. Despite this fact, a political reading of the textbooks - textbooks as cultural production - has not drawn sufficient critical attention in school textbook research.

Though only a few studies concentrate on the representation of history in them, they are worth reviewing. Bennike's study on textbooks of the Panchayat era to 2009 AD reports on how textbooks were "only a medium for transmitting the Panchayat state's discursive representations of national space" (58). Bennike argues that Panchyat used textbooks for nationalizing the brave past, portraying Nepal as an organized and harmonious space via the slogan of "four castes and thirty-six sub-castes" (59). However, Bennike does not consider the absence of critical awareness about the history that is likely to lead students to "accept passively their places in society rather than to take a more active role in determining their experiences and their positions within society in order to transform the society" (GC 1491). In fact, with the specific focus on Balbhadra Kunwar, Pratyoush Onta had already argued that the Panchayat era textbooks served the 
making rashtriya itihas ('national history'). He stated that textbooks "drew upon extant narratives of certain events but carefully pruned to make the final versions reproduced for schoolbooks fashion a bira ('brave') and virile image of the nation" (231). Similarly, according to Upadhyaya, the textbooks exhibited two important agendas: textual cultivation of religious agenda, and obsession with the nationalist discourse that mainly protrudes from the saga of brave history (116). Despite these reviews, a study focusing more on how the textbooks compilers made political use of historical facts to construct a homogenized national narrative has not been a matter of concern.

The primary purpose of this paper is to explore how bira ('brave') history has been constructed and applauded in school textbooks ${ }^{2}$ and how it is made to be acknowledged by the students by focusing only on the comfortable facts and evading what is ambivalent - the facts that impede the glorification of the supposedly historical past. Moreover, it tries to explore if the textbooks let students be informed about contradictions that have resurfaced in recent years about those historical facts and events. Therefore, this paper will attempt to answer this question: Are the students expected to be the responsible and critical readers of history, or opposite of it - the shallow or sketchy ones?

\section{Methodology}

To address the objective of the study, this paper has used the Critical Discourse Analysis (CDA) as a method since it attempts "to uncover, reveal or disclose what is implicit, hidden or otherwise not immediately obvious in relations of discursively enacted dominance or their underlying ideologies [...]" and "focuses on the strategies of manipulation, legitimation, the manufacture of the consent and other discursive ways to influence the minds (and indirectly the actions) of people in the interest of the powerful" (Van Dijk 18). Moreover, the task of critical discourse analysis is both deconstructive and constructive. In its deconstructive strategy, it aims to disrupt and render the problem of themes and power relations of everyday talk and writing. To deconstruct the discourse of the brave history, three historical figures - Bhimsen Thapa, Balbhadra Kunwar, and Prithvi Narayan Shah - have been taken as representatives of personification of bìra gōrakhali ('brave Gorkhas'). Constructively, it has been applied to develop a critical literacy that aims towards an expansion of students' capacities to critique the discourse and social relations, and towards a more equitable distribution of discourse resources.

More specifically, the paper engages Fairclough's "three-dimensional framework" of conceiving and analyzing discourse (Fairclough 4). To explore the representation of the history in school coursebooks, the first level of sampling involved selection of the subjects like Nepali and Social Studies (20 textbooks, grade one to ten), as the major corpus of the study, where the topics related to Nepali history are likely to be included. The individual texts on Bhalabhadra Kunwar, Bhimsen Thapa, and Prithvi Narayan Shah, purposively selected constitute the discourse as text, the linguistic features, and the organization of concrete instances of discourse. Secondly, the saga of bravery as represented and constructed in the textbooks forms the discourse as practice, discourse as something that is produced, circulated, distributed, and consumed in society. This is also a "macro condition" for circulation and distribution of the discourse (Fairclough 72). The teaching-learning activity, which involves all three important stakeholders: students, teachers, and textbooks, constitutes the third dimension as discourse as social practice, the behavior and thinking the ideological effects, and hegemonic processes aim at producing.

\section{The Use of National Heroes in Textbooks}


Teaching History of Bravery and the Politics of Textbooks in Nepal 27

A close explication of the history contents prescribed for the curriculum of government schools yields that the history has been made an agreed-upon knowledge to feel proud, giving it objective credence. The current composition and creation of content related to history embark only the comfortable aspects of our history instead of making this an opportunity to revisit and seek the disjuncture and rifts in it, thus empowering students to develop a critical lens and questioning attitude. The evasion of the odd facts about the history in schooling periods, according to Hobsbawm, provides the "most powerful weapon for forming . . . nations" (120). The textbook compilers can employ history education to unify the nation under the state and to homogenize the population by instilling pride and loyalty to the nation over anything else. I begin with a stanza of the poem "Jhanda Pharar" ('Flag Flapping') by Madhav Ghimire in Hamro Nepali Kitab Kaksha Dui is totalizing and magnifying:

Pashchim killa kaanggada, purwamaa tishtaa pugethyau.

Kun Shaktiko Saamumaa Kahile Haami Jhukethyaun.

Haamile himal uthayau yesiyaako maajhamaa

Sabhyataako waas basethyaun aayera yahi sanjha maa.

We reached the East fortress and Kāngadā to the west.

Never bowed down before any sort of power.

We succeed to create a nation amidst Asia.

We created our own civilization at the very moment of victory. (my trans.; 86)

This stanza does not question the past to irradiate the present but uses it as a touchstone to orient the students toward the path of morality. Similarly, the contents and episodes of history are used as a simple-minded morality play in the school textbooks. There is nothing wrong to present historical shreds of evidence as facts; however, the problem lies in deploying the historical facts to reconstruct the past - the value of the past, the serenity of past, idealistic and idyllic past (Lukacs 105-108). The stanza appreciates the deeds executed by braves without naming the officially "acclaimed" national heroes: Bhimsen Thapa, Bhalabhadra Kunwar, Bhakti Thapa, and later on Prithvi Narayan Shah. In the stanza, the poet even claims that the brave "created" a nation in Asia. This is not true; Nepal was there as a sovereign country before the foreign attempted invasion. The incorporation of the texts like this tries to glorify bìra itihāsa ('brave history'), which has been the central content of teaching history in the school textbooks in Nepal. The oftquoted message extracted from these texts is a historical morality - as you have a proud heritage, you are supposed to act accordingly to preserve the heritage. The following sections specifically focus on three important figures in history and try to identify how history has been negotiated and maintained by keeping critical learning/teaching of history at its disposal.

\section{Bhimsen Thapa and Trauma of Sugauli Treaty}

Thapa is represented as the ideal governor, filled with a vigorous spirit of love for the nation's territory. He is characteristically described as courageous, daring, enduring, commanding, and militant. His major contribution is recounted as a formulator of strategic military policy improvements against the probable assault by the foreign, the then residing adjacent to Nepal's territory, and modernization of military (Hamro Samajik Adhyayan Kaksha Paanch 76). However, what was unfitting and uncomfortable regarding the national hero has always been submerged and homogenized. For example, in Hamro Nepali Kitab Kaksha Nau, it is written: "unako shaasankaalmaa sugauli sandhi garetaa pani, unale rashtrako saarvabhaumata, swatantrata ra ekataamaa aanch aauna diyenan" 'though Sugauli Treaty was formed in his period of reign itself, he never let to encroach into nation's liberty, freedom, and national integrity' (my trans.; 89). The 
Teaching History of Bravery and the Politics of Textbooks in Nepal 28

intention to highlight the brilliant aspect of Thapa has been statistically managed in the sentence. The subordinate sentence structure of this expression inherently assumes something was wrong with the Sugauli Treaty; however, attention has been given only to draw upon the "brilliant" aspects of Bhimsen Thapa through the use of the independent clause.

Despite this magnified brilliance of Bhimsen Thapa, particularly regarding the treaty, numerous critical comments against the proposed glory of Bhimsen Thapa have emerged. This treaty in Nepal's history is taken as having unbearable pain and traumatic feeling in terms of sentiment, and geography, above all, national pride. It is thoroughly condemned. The sign of treaty preceded long discussion and disputes. First, the British India put many unnecessary and inappropriate terms and conditions in the treaty (Baral and Pyakurel 4). At first, Nepal did not accept the conditions. However, at last, to protect its independent existence, Nepal accepted the treaty on 3 March 1816 AD so as to avoid another possible war. The East India Company had been successful to acquire the onesided benefits through the treaty of Sugauli. Nepal had to lose one-third of the total land under its control. Second, it also affected the foreign policy of Nepal. Nepal was compelled to let the Residency of British Government stay in Nepal (Pattanaik 467). Sugauli Treaty formally ended the "unification/expansion" campaign of Nepal. The mission of Nepal to expand its boundary up to river Ganga remained unfulfilled. Nepal was compelled to remain with constriction as the boundary of the Company Government surrounding it from three sides. As a result of the treaty of Sugauli, the British Government had been successful to keep its minister (residency) in Nepal. The prime objective of the British behind establishment of Residency in Nepal was to fulfill their interests through the rulers of Nepal by interfering in the politics of the country. Although they were not successful in their objective in the beginning, but later the British ambassadors had been able to influence the politics of Nepal (Riaz and Basu 8).

However, the textbooks compilers give no attention to the problems that have surfaced about the Sugauli Treaty. Instead, an urge to pay homage to the national icon has been centralized. For instance, a stanza of praise, highlighted in colorful box, preceding the text entitled "Bhimsen Thapa" in Hamro Nepali Kasksha Nau, poses a couple of rhetorical questions: "Waastav maa haamile haamro itihasmbaare kin garva garchhau? Ke hamile yasko laagi haamro purkhaa laai yasko laagi shreya dinu pardaina ta?" 'Why do you actually feel glory and pride about our history? Do you not have to credit our brave ancestors for it?' (my trans.; 86). Subsequently, a very positive and normative answer follows. In addition, the historical biography of Bhimsen Thapa begins. Here is a short excerpt from the biography:

unale aafno shaasankaalmaa angrej sangako yuddha pachhi sugauli sandhi garee samjhauta garnu paretaa pani unle raashtriya sarwabhaumta, swatantrata ra abhibhaajyataako sawaalmaa maa kunai aanch aauna diyenan. yasko atirikta angrejko aupaniweshik ra wistarbaadee rananitilaai safal huna diyenan.

Though he [Bhimsen Thapa] during his regime, after the war with British, had to compromise with Sughauli Treaty, he did not let any trespassing regarding national sovereignty, freedom, and national indivisibility. In addition to this, he did not let be successful the Britisher's colonial and expansionist policy. (my trans.; 87)

While textbooks conform to placid depiction of Bhimsen Thapa, they are silent about questionable repercussions of his moves. It is during Bhimsen Thapa's premiership that the Anglo Nepal War was fought and it is during the same period that Nepal suffers from the trauma of defeat in which it loses much of its territory. Much of the miseries that 
Teaching History of Bravery and the Politics of Textbooks in Nepal 29

Nepal is facing from the issues of nationalism to the issue of economic insufficiency stems from this traumatic loss of war (Stiller 86-87).

In fact, the root of revulsion against that southern neighbor India lies in the very defeat and the treaty that followed. Pre-1816 Nepal was an empire. It had annexed Kumaon and Grahwal, and had expanded as far as Satlaj River. But, the defeat of Nepal in 1814-1816 has amputated Nepal's territory to its present size (Savada 50). With the treaty of 1816, when permanent residency was allowed in Kathmandu, the concept of the Nepali nation as pure Hindustan starts to lose its former vitality. By 1816, Kathmandu started to populate the "firangi ${ }^{3 "}$ and the realm has officially been defiled for the first time after Prithvi Narayan had evicted the "defilers". Consequently, Nepal gradually began to lose its vitality as a purely Hindu nation. According to Acharya, after this, Bhimsen Thapa slowly started becoming English friendly: he did not object to sending the little general Mathabar Singh Thapa to London, and nor did he refrain from talking counsels from the resident in Lainchaur about the State of affairs at home (Acharya Janaral Bhimsen 49).

Bhimsen Thapa is believed to have been the longest-ruling mukhtiyaar ('prime minister') of Nepal besides Jung Bahadur. He ruled between 1812 to 1837 BS. During his premiership, Nepal had annexed Kumaon and Garhal and had expanded as far as the Satlaj River. He rises to power when Nepal is undergoing a fluid political situation following the whims and tantrums of the then king Rana Bahadur Shah. It was out of Rana Bahadur's insanity that Bhimsen Thapa rose to an absolute power (Regmi, Military and Democracy in Nepal 38). During this time Bhimsen and Nepal were synonymous. (Pradhan, Thapa Politics in Nepal 189). Bhimsen on his part was always opposed to British India government: "He looked upon the company as his foe rather than his friend. He was determined to see how far he could remove his neighbor's landmarks to the south without encountering serious opposition" (Landon 83). He is known to have said to his advisors on the eve of Anglo-Nepal war: "How . . . will the English be able to penetrate into the hills?" ... [we] will expel them ... Our hills and fastness impregnable. I, therefore, recommend hostility. We can make peace afterward on such terms as may suit our convenience" (Princep 458).

Nevertheless, as much as Bhimsen Thapa is eulogized for his anti-British stance he is also criticized for raising his position with and in support of the very foes he wanted to chase away. After the fall of Damodar Pandey, who was dethroned from mukhtiyari because of his supposed association with the British rulers in the south, Bhimsen Thapa rose to power. But, he rose to "power when he supported the British cause" (Acharya, Janaral Bhimsen 18). Acharya, similarly, mentions that Bhimsen Thapa declared war in 1814 out of his arrogance: he had no war skills; when he was in absolute power, he concentrated his attention in consolidating power to serve his and his family's interest, and around 1810s, he was a skilled player of contrivances and conspiracy but lacked diplomatic craftiness (54). He went for war despite the advice from his advisors that the controversial Terai lands, which were the bone of contention between the Company government and Nepal and on which the British raj had laid its claim, had to be left for the British to avoid war. But, Bhimsen Thapa's disregard of advice made the war inevitable. However, Bhimsen Thapa is considered a never-forgotten historical icon in the Nepali consciousness; anything ambivalent about the historical figure has been pruned and hailed as the bastion of Nepali bìra itihāsa.

\section{Gendered and Mercenary Status of Balbhadra}

The Khalanga Nalapani Anglo-Nepal War episode, led by "20-years old Captain Balbhadra Kunwar", is another instance endorsed in textbooks to represent the historical 
glory of national integrity and bravery (Hamro Samajik Adhyayan Kaksha Nau 178). Balbhadra Kunwar is an emblematic representative of the brave fight against the military of the East India Company, led by General Sir Robert Rolls Gillespie, and is also known for his perseverance and undefeated self as he tore the letter sent by the general to surrender. To show Balbhadra Kunwar's bravery, perseverance and undefeated self, his status in the war has been described that he was accompanied by only 600 persons, including women and children, and he was not in a better position to fight against the British militarily troops, equipped with eight times more than Nepali troops having only Nepali canon, archery and khukuri (178). The accounts of description constitute that the battle was, by all accounts, fierce: fort became unbearable due to lack of water and other supplies, and due to the continuous bombardment by the British; Balbhadra Kunwar and some of his subordinates had to escape to another location; The second British assault was launched weeks later after reinforcements; Balbhadra Kunwar is said to have denied blandishments and bribery offered by the British armies (Hamro Samajik Adhyayan Kaksha Paanch 74). Wherever details are given, this current historiography negotiates and maintains at least two important aspects regarding bìra itihāsa.

First, the Nalapani episode has been used as an appropriated but suitable occasion to appraise the sacrifice of Balbhadra Kunwar as well as to define the notion of bravery. In an acute sense, bravery has been appraised as the capacity to challenge the imperial forces, deemed as evil. Complying with many historical documents on this incident, the textbooks present that, at that time, Nepal's sovereignty was on the verge to be challenged by the evil imperial forces dominantly launched by the East India Company, and was extending its grip towards the territories of the Himalayas. The Nalapani war episode in many lessons has been represented as a sheer occasion on which the bira Nepali can exhibit their sacrifice and individual price, for that matter, the life itself, to prove the amount of dedication and love to their nation and the king. Moreover, Balbhadra Kunwar is quoted as roaring "durga lina sakne kasaiko saamarthya thiyen tar aba haamee aafno ichchhale yo chhaddai chhaun" 'nobody had the capacity to take the forte; but we are leaving it voluntarily' (Hamro Samajik Adhyayan Kaskha Nau 178). Then only they demolished the fort and built a stone inscription in the praise of Balbhadra Kunwar.

While these details of the war are historically endorsed in the government school textbooks, anything ambivalent, critical and diffident historical accounts that go against the characterization of Balbhadra Kunwar as a bira purușa ('brave person') has been excluded from the lessons. About Balbhadra Kunwar, an extended countervailing overview comes from Gyawali's write-up. Gyawali mentions that after the treaty of Sugauli, Balbhadra Kunwar died fighting for Sikhs against the Afghans (13-15). He died fighting for the foreign country as a mercenary, still his death is regarded as a "brave death." However, no account in the textbooks has been presented about his mercenary status. The reasons behind what Balbhadra Kunwar encouraged to join the foreign army while he was considered the hero of Nalapani and as an inherent embodiment of bira itihāsa has never been the part of learning history about him. Furthermore, while talking about his death, the textbooks simply state that Balbhadra Kunwar was born in a brave family, he fought bravely for the country and died fighting in a war. "It is never stipulated in the units why the national hero stills remain as "one of our eternal national heroes" even after acknowledging that he died in some other land fighting for other nation, nor is it clarified he still deserved a deifying honor of heroism for his Nalapani episode (Onta 20-25). As how he died becomes a controversial issue, textbooks are silent about the critical link between recounting of Balbhadra Kunwar's supposedly daunting bravery and his mercenary service to Ranjit Singh has deliberately been excluded. 
Teaching History of Bravery and the Politics of Textbooks in Nepal 31

In addition, the notion of bravery as depicted in the textbooks is gendered. The bravery has been delineated as a pure masculine feature and a celebration of Nepali nationhood and a reminder of one's duties as a citizen of Nepal that rests on being bira purūṣa ('brave man'). But, we need to note that Balbhadra Kunwar's wife and other women in the fort participated in the war. However, the textbooks never treat this fact with significance. Hence, their role is rendered as a subsidiary of the contribution made by Balbhadra Kunwar and his men. Bravery has completely been deemed as an exclusive masculine feature, and only the bìra purūṣa ('brave man') can brandish this.

\section{Ifs and Buts on Prithvi Narayan Shah}

Prithvi Narayan Shah is an ever-present national icon in historical consciousness of Nepali and Nepal. In historical documents, he is known as the one girded for battle and whose success is greatly documented as a result of sound logistical preparations and "more on his political skills and a shrewd combination of conciliation and intimidation" (Wheplton 35). And because of his incessant victories over the then scattered raajyas ('principalities') as part of annexation of his own original Gorkha state, he famously resides "the maker of modern Nepal" (Regmi, Modern Nepal vi-vii). Following the same cult, the school textbooks faithfully recognize bravery of Prithvi Narayan Shah especially in two respects.

First, like many Nepali history documents, the textbooks adjudicate Prithvi Narayan Shah as the maker of modern Nepal, the unifier who strengthened the nation and enhanced nationality was an excellent ruler, strategist par excellence, and a champion of psychological warfare who maintained harmony among the different castes and ethnicities and was single-mindedly looking into the business of ruling a kingdom (Hamro Samajik Adhyayan Kasha Nau 174). Moreover, his dibyopadesh - Nepal as a garden of four castes and thirty- six jaatsi has been used to characterize him as being concerned with democratic values and inclusiveness. A unit "Nepalko Ekikaran" 'Unification of Nepal', epistolary in form, in Hamro Samajik Adhyayan Kasha Aath portrays Prithvi Narayan Shah being prophetic in terms at least in two respects: appointment of Kalu Paande was an instance of respect to people's voice which shows his democratic character, his dibopadesh - Nepal as a garden of four castes and 36 jats was an expression of inclusiveness (100-101).

Despite such proclaimed historical evidence, Prithvi Narayan Shah's unification is not taken with ease. He has been revisited as an expansionist as well as internal colonizer. One critical voice against the glory of unification is that it was not the unification but expansion of the Gorkha that involved confiscation and violence. According to Pradhan asserts the expansion was "more than a punitive expedition" (The Gorkha Conquest 117). Thus, though the possibility of an outright conquest of the western principalities had been mooted before, all that Prithvi Narayan Shah desired at this juncture was to establish his lordship over them (Pradhan, The Gorkha Conquest 118). One famous dibyopadesh - mera saanaa dukha le aryaa muluk hoina 'this will not be my little painfully acquired kingdom ${ }^{\prime 4}$ - also implies his desire to establish lordship, ventured through economic oppressions and bloodbath. For example, Regmi notes that "King Prithvi Narayan Shah had confiscated the birta rice-lands of the inhabitants of the Dhulikhel when he conquered that area. (Regmi Lecture Series 5)

The starker example of atrocity is exemplified also with a reference to the historical conquest of Prithvi Narayan Shah over Kirtipur in which he is "blamed" to have cut the noses of many people, including the women, merely to expand his regime (Wright 259; Waller 171). In this reference, even B.P. Koirala who is supposed to have closely observed the historical and political upsurge of Nepal also holds a critical view on Prithvi 
Teaching History of Bravery and the Politics of Textbooks in Nepal 32

Narayan Shah. He observes Prithvi Narayan Shah had such strategies, which were filled with blind anger and motives of revenge, he would take the help of hooks and crooks until he would get a victory, but after the victory, he would launch a tandava $a^{5}$ of violence ${ }^{6}$.

The claims also prevail in Madhesi, Janjati, Aadibasi and Newari communities that Prithvi Narayan Shah was unfair in "colonizing" the Terai, the Kirant regions, and the Kathmandu valley. While a common apprehension - Prithvi Narayan Shah as an eternal national icon in the national imagination - is "tenaciously attached to Nepal in general by the mainstream Nepali history, today's critical political scrutiny sees in it the roots of a long-standing rule of dominance over and marginalization of many ethnic communities" (Kafle 143-44). Debates about the formation of modern Nepal have the issues of Madhesis, Janjatis, and Newars of Kathmandu regarding the unification and establishment of Nepal as a nation-state. In this regard, Pradhan also argues that the Gorkhali's new state "did not unite the segregated groups brought under the unified kingdom: on the contrary it divided them" (The Gorkha Conquest 201).

Second, Prithvi Narayan Shah is exclusively credited as an eternal icon for cultivating nationalistic feelings basically founded upon aversion for foreignness (the then British and now India). However, recent historians see this as a mere rhetoric of creating Nepal as an abode of ideals of Hinduism, and a strategy of streamlining the classical Hindu hierarchical structure. After his Kirtipur conquest, Capuchins were barred with whom he previously had a cordial relation; "the gosain (Indian ascetic) merchants, whom Prithvi had cultivated during his campaign against the Valley states, were expelled and British attempts to establish trading relations and access to Tibet were rebuffed" (Whelpton 38). Similarly, Stiller notes that Prithvi Narayan Shah dictated a strict control on merchants and foreign imports, banned dancers, musicians, wrestlers, and other entertainers from Mughal India (46). Similarly, like Malla rulers, he mandated a timeconsuming rite of ritual purification be performed for any Nepali returning from outside the Hindu world. However, as for travelers into the valley, those who were perceived as being Hindu, with more or less equivalent customary laws, were not considered as threats to the purity of the realm and threat to Hindu morality (Liechty 11). With these maneuverings, he tried to project himself as the protector of perhaps the last "true Hindustan".

Similarly, his famous dibyopadesh - Nepal as a garden of four varnas ('major castes') and thirty-six jaats ('types of castes'), conventionally understood as "endorsing a policy of ethnic harmony and coexistence" is in fact debated as a strategy of keeping Hindu structure intact and caste purity (Gellner 23). However, after the fall of Shah dynasty, "garden of four castes and thirty- six jaats" was translated and enacted quite differently later by Junga Bahadur Rana as dictated Muluki Ain as an instance of law and caste hierarchy as progressive legal policy. However, this ironically excluded the legal identity of many ethnicities and castes (Pradhan, "Ethnicity, Caste, and a Pluralist Society" 106). In this structure, the Brahmans and Kshetris are granted privileged positions while vaishyas and shudras were relegated to serve the ruling classes. Moreover, the ethnic nationalities have hardly ever reached in the helm of power in Nepali history. In reality, as Thapa argues,

... just three groups ruled the country. The Chhetri caste, including the Shahs Thakuri sub-caste and the Ranas, controlled the palace, the court, and the military. . . everyone in power was the Chettris, Bahuns, and Newars. . . more than 90 percent of the country's population found no representation at all. (Forget Kathmandu 52-53). 
Teaching History of Bravery and the Politics of Textbooks in Nepal 33

Since the time of the Sugauli Treaty of 1816 (3), passing through the 1950s and1990s, and coming to the 2000s, the kind of intense crisis besetting the central Nepali state founded under the leadership of Prithvi Narayan Shah more than 225 years ago, it was not and is not possible for it to maintain itself in the same old form and under the same old historical knowledge. Moreover, in Nepal's special geopolitical context and the changing situation of the rapidly transforming balance of power in the world and South Asia, it was and is becoming extremely difficult to preserve the definition of Nepal's national unity and sovereignty in the old form. Similarly, Nepali identity as a birā gōrakhali has also undergone a tremendous amount of change. Despite these historical eccentricities, the naïve and linear reading of Prithvi Narayan Shah in school textbooks has long been endorsed.

\section{Conclusion: Learning Historically ${ }^{7}$}

The selection of history contents for the school textbooks shows the utter obsession with telling positive and historically dubious stories about the national past. The preoccupation with the cult - the transmission of a positive story about the national past to inspire a sense of loyalty to the nation at the disposal of critical understanding of the history - gives rise to teaching history as a political agenda. The children then happen to learn the indoctrinated history. To sum up, the responsible readers of history, however, should not go after one viewpoint only. For example, to see only the weaknesses of Prithvi Narayan Shah by highlighting the myths of cruelties is to be deliberately blind and deaf towards his contributions. Similarly, to see only the glory of unification, conquest, and integration curbing aside the cruelties and oppression is equally false. Young people have every right to know and understand "deficits" of the past and its heroes as well as the advantage of it.

A recessive nostalgic and rose-tinted articulation of history will not provide pupils with an understanding of the world in which they will grow up, nor will it be conceivable and credible. Given that in a world of the internet, where myriads of learning sources are available, schools are no longer the only or even the main source of information about history. Instead, the goal of historical study should be to teach us what we cannot see, to acquaint the students with the ingrained blurriness of our vision.

School history needs to take account of these changes and students should have the right to know the alternative narratives to develop a critical attitude toward the created reality or pupils will see it as a quaint irrelevance. Hence, the textbooks should be able to teach history as the bodies of knowledge about the past produced by historians, together with everything that is involved in the production, communication of, and teaching about that knowledge.

\footnotetext{
${ }^{1}$ There is a rigorous debate among the Nepalese intellectuals whether the mission of Prithvi Narayan Shah to conquer the then principalities of Nepal was a process of unification or expansion of his original Gorkha state.

${ }^{2}$ The schoolbooks for analysis include textbooks on Nepali and Social Studies from class 2 to class 10 that were primarily published between promulgation of Constitution of Nepal-2047 (BS) and Interim Constitution of Nepal 2072 (BS)

${ }^{3}$ A foreigner, especially a British and a white person in this context.

${ }^{4}$ This is Stiller's translation. See more at Stiller, L. F. Prithvi Narayan Shah in the light of Dibya Upadesh. Himalaya Book Centre, 1968, pp. 44.

${ }^{5}$ tandava is a form of wild and uncontrolled divine dance especially performed by Lord Shiva.

${ }^{6}$ Recent critical voices try to revisit Prithvi Narayan Shah and debunk the worshiping and pedestal position given to Prithvi Narayan Shah. See Ludwig Stiller, The Rise of House of
} 
Teaching History of Bravery and the Politics of Textbooks in Nepal 2

Gorkhas, Ratna Pustak Bhandar, 1993, and Rajendra Maharjan (January 23, 2014). "Ma Nakati Kirtipur Naak Magdaichhu" Kantipur Daily.

${ }^{7}$ This term here specifically refers to a special approach of reading history developed by Thomas Andrews and Flannery Burke. It refers to five C's of historical thinking - the concepts of change over time, causality, context, complexity and contingency. See "What Does It Mean to Think Historically?" for more details at historians.org/publications-anddirectories/perspectives-on-history/january-2007/what-does-it-mean-to-think-historically.

\section{Works Cited}

Acharya, B. Janaral Bhimsen Thapa: Yinlai Maile Jasto Dekhen (General Bhimsen Thapa: The Way I Saw Him). Ratna Pustak Bhandar, 2008.

Adhikari, I. Military and Democracy in Nepal. Taylor \& Francis, 2017.

Andrew, Thomas and Flannery Burke. "What Does It Mean to Think Historically?" Perspectives on History, 1 Jan. 2007, www.historians.org/publications-anddirectories/perspectives-on-history/january-2007/what-does-it-mean-to-thinkhistorically.

Baral, Lokraj and U. P. Pyakurel. Nepal-India Open Borders: Problems and Prospects. Vij Books India Pvt Ltd, 2015.

Bennike, Rune Bolding. "Textbook Difference: Spatial History and National Education in Panchayat and Present-day Nepal." The Indian Economic \& Social History Review, vol. 52, no. 1, 2015, pp. 53-78.

Bermúdez, Ángela. "The Discursive Negotiation of Narratives and Identities in Learning History." History Education and the Construction of National Identities, edited by Mario Carretero, Maria Rodriguez-Moneo and Mikel Asensio, Information Age Publishing Inc., 2012, pp. 203-219.

Carr, E. H. What is History? Pelican Press, 1961.

Carretero, Mario, et al. History Education and the Construction of National Identities. Information Age Publishing Inc, 2013.

Fairclough, N. Discourse and Social Change. Polity Press, Cambridge, 1992.

Ferro, M. The Use and Abuse of History: Or How the Past is Taught to Children. Routledge, 2004.

Foucault, Michel. The Foucault Reader, edited by Paul Rainbow. Penguin, 1986.

Freire, P. Pedagogy of Freedom: Ethics, Democracy, and Civic Courage. Rowman \& Littlefield, 1998.

GC, Saroj. "Killing the Critical: A Critical Discourse Analysis of Moral Values in Government-sponsored Textbooks of Nepal." International Journal of English Literature and Social Sciences, vol. 5, no. 5, 2020, pp. 1483-1493, https://doi.org/10.22161/ijels.55.22.

Gellner, David N., et al. Nationalism and Ethnicity in Nepal. Vajra Publications, 2008.

Grever, M., \& Van der Vlies, T. "Why National Narratives Are Perpetuated: A Literature Review on New insights from History Textbook Research." London Review of Education, vol. 15, no. 2, 2017, pp. 286-301.

Gyawali, S. B. Bir Balbhadra. 3rd Ed. Ratna Pustak, 1956.

Hamro Nepali Kitab Kasksha Dui (Our Nepali Book Class 2). Government of Nepal Ministry of Education Curriculum Development Centre, 2012.

Hamro Nepali Kitab Kasksha Nau (Our Nepali Book 9). Government of Nepal Ministry of Education Curriculum Development Centre, 2012. 
Hamro Samajik Adhyayan Kaksha Aath (Our Social Studies Class 8). Government of Nepal, Ministry of Education and Curriculum Development Center, 201.

Hamro Samajik Adhyayan Kaksha Nau (Our Social Studies Class 9). Government of Nepal, Ministry of Education and Curriculum Development Center, 2016.

Hamro Samajik Adhyayan ra Srijanatmak Kala Kaksha Paanch (Our Social Studies and Creative Arts Class 5). Government of Nepal, Ministry of Education and Curriculum Development Center, 2013.

Hobsbawm, E. Age of Capital: 1848-1875. Hachette UK, 2010.

Issitt, John. "Reflections on the Study of Textbooks." History of Education, vol. 33, no. 6, 2004, pp. 683-696.

Kafle, H. R. "Prithvi Narayan Shah and Postcolonial Resistance." Bodhi: An Interdisciplinary Journal, vol. 2, no. 1, 2008, pp. 136-147.

Liechty, M. "Selective Exclusion: Foreigners, Foreign Goods, and Foreignness in Modern Nepali history." Studies in Nepali History and Society, vol. 2, no. 1, 1997, pp. 5-68.

Lukacs, John. Historical Consciousness: The Remembered Past. Transaction Publishers, 1968.

Marwick, Arthur. The Nature of History. MacMillan, 1989.

Onta, Pratyoush. "Ambivalence Denied: The Making of Rastriya Itihas in Panchayat Era Textbooks." Contributions to Nepalese Studies, vol. 23, no. 1, 1996, pp. 213-254.

Pattanaik, Smruti S. "Indo-Nepal open border: Implications for bilateral relations and security." Strategic Analysis, vol. 22, no. 3, 1998, pp. 46-478, https://doi.org/10.1080/09700169808458825.

Porat, Dan. "A Contemporary Past: History Textbooks as Sites of National Memory." International review of history education: Raising standards in history education, edited by Alaric Dickinson, Peter Gordon, Peter Lee, Routeledge, 2001, pp. 36-55.

Pradhan, K. L. Thapa Politics in Nepal: With Special Reference to Bhim Sen Thapa, 1806-1839. Concept Publishing Company, 2012.

Pradhan, K. L. The Gorkha Conquests of Eastern Nepal and Sikkim. Himal Books, 2009.

Pradhan, Rajendra. "Ethnicity, Caste and Pluralist Society." Perspectives on Modern South Asia: A Reader in Culture, History, and Representation Vol. 6, edited by Kamala Visweswaran, John Wiley \& Sons, 2011, pp. 100-110.

Prinsep, Henry Thoby. History of the Political and Military Transactions in India during the Administration of the Marquess of Hastings, 1813-1823. Vol. 2. Kingsbury, Parbury \& Allen, 1825.

Regmi, D. R. Modern Nepal: Rise and Growth in the Eighteenth Century. (vol. I \& II). Rupa Publishers, 1961.

Regmi, Mahesh Chandra. Regmi Research Series. Digital Himalaya, 1978.

Riaz, Ali and Subho Basu. Paradise Lost? State Failure in Nepal. Lexington Books, 2007.

Savada, Andrea Matles, editor. Nepal: A Country Study. GPO for the Library of Congress, 1991.

Smith, Anthony D. National Identity. Vol. 11. U of Nevada P, 1991.

Stiller, Ludwig F. The Silent Cry. Sahayogi Prakashan, 1976.

Thapa, Manjushree. Forget Kathmandu. Penguin Books, 2001. 
Tosh, John. The Pursuit of History: Aims, Methods and New Directions in the Study of History. Routledge, 2013.

Upadhyaya, Phanindra Kumar. Politics of Hegemony and Denial in the Rhetoric of Language and Education Policy in Nepal: A Critical Discourse Analysis of Policy Documents and Government-sponsored Textbooks (1960-2009). The University of Texas at El Paso, 2010.

Van Dijk, Teun A. "Aims of Critical Discourse Analysis." Japanese Discourse, vol. 1, no. 1, 1995, pp. 17-27.

Waller, Derek J. The Pundits: British Exploration of Tibet and Central Asia. UP of Kentucky, 2004.

Whelpton, John. A History of Nepal. Cambridge UP, 2005.

Wright, Daniel, ed. History of Nepal: With an Introduction Sketch of the Country and People of Nepal. Asian Educational Services, 1990. 